\title{
Anal Cancer Clinical Distant Metastasis TNM Finding v7
}

National Cancer Institute

\section{Source}

National Cancer Institute. Anal Cancer Clinical Distant Metastasis TNM Finding v7. NCI

Thesaurus. Code C90028.

A clinical finding about one or more characteristics of anal cancer, following the rules of the TNM AJCC V7 classification system as they pertain to distant metastases. 